\title{
The XXI Century Foreign Language Textbook as a Challenge for Publishers
}

\author{
Sergey A. Letun (a), Lyudmila A. Voronina (b)* \\ (a) Moscow City University, 129226, Moscow (Russia), 4-1, $2^{\text {nd }}$ Selskokhoziastvenny Proezd \\ (b) Moscow City University, 129226, Moscow (Russia), 4-1, $2^{\text {nd }}$ Selskokhoziastvenny Proezd \\ LyudaVoronina@gmail.com
}

\begin{abstract}
Publishers of textbooks has faced new challenges as a natural consequence of rapid changes in the digital age. Nevertheless, the understanding of a "textbook" by a teacher of a foreign language and a publisher still differs. There is necessity to integrate course series with web applications suggesting adjustments to the usual way of working for publishers. The article deals with creation of the shape of the XXI century foreign language textbook and determination of its characteristics distinguishing an innovative textbook from its traditional model to list services that publishers should be ready to provide to teachers-developers of the technologies in teaching foreign languages in order to jointly create an innovative e-textbook that meets modern reality and trends. The analytical study showed how the concept of e-textbook changed in a chronological order in comparison with the concept of paper textbook. Interactivity, information polymodality and hypertext structure is considered fundamental difference between an etextbook and its paper counterpart. The authors generalized the services that a modern publisher should be ready to render to teacher-developers and to universities, and formulated the conditions under which the teacher-developer's readiness to implement digital technologies in making modern e-textbooks can be achieved. It was stated that technological learning platforms should be a kind of integration with publishing platforms at the same time, and the conclusion was made as to how XXI century textbook on a foreign language can be defined.

Keywords: textbook concept; integrated learning and publishing platform.
\end{abstract}

\section{(C) 2021 Sergey A. Letun, Lyudmila A. Voronina}

This is an open access article distributed under the terms of the Creative Commons Attribution License (CC BY 4.0), which permits unrestricted use, distribution, and reproduction in any medium, provided the original author and source are credited.

Published by Moscow City University and peer-reviewed under responsibility of TSNI-2021

\section{Introduction}

(Textbook: Focus on Students' National Identity)

The exponential increase of e-book distribution is a natural consequence of the digital age. Technological achievements make it possible to download, customize, print or send e-books anywhere. When searching for information, students instantly join current trends easily accepting new technologies and expecting a similar response from automated systems that distribute the content they request (Manzoor, 2016). The industry of academic publications has no other choice but to respond to this growing demand: in modern

\footnotetext{
* Corresponding author. E-mail: LyudaVoronina@gmail.com
} 
society the question of the necessity to transform the concept of "textbook" including a foreign language textbook has become quite actual. And the main challenge should be taken by a publishing house as the main producer of the textbook as a final product.

In the most general sense, the understanding of a "textbook" by teachers of the foreign languages and publishers differ: in the first case, the emphasis is on a learning model (Bim, Afanas'eva, \& Radchenko, 1999), which is implemented by the teachers, and in the second case the publishers focus on a form, i.e. structural components and their organization, in accordance with which "educational publications" are subdivided into twelve titles within the framework of the Russian state standard (GOST 7.60-2003). The detailed analysis of the concept of "textbook" from both points of view suggests that the publishers understand the "textbook" rather formally and are interested only in compliance with the specified standards, but for teachers the "textbook" is classified in different ways and performs different functions, where the most important functions are considered as: informing, teaching, motivating and controlling (Azimov \& Shchukin, 2019). The last interpretation of the term reflects the characteristics of teaching a foreign language, which has a pronounced practice-oriented nature, therefore the name "textbook" accepted among teachers often means "training aid" or "learning aid". At the same time the latter, considering modern pedagogical trends in terms of acquiring an increasingly active role by learners in the educational process, acquires the features of a learning and methodical aid (LMA) due to the presence of methodological recommendations there.

The purpose of the "learning aid" is "formation of one of the aspects or types of speech activity" (Azimov \& Shchukin, 2019), therefore, for teaching a foreign language, a "typical course series" is necessary implying a set of learning aids with varying degrees of dominance of one of such aspects or types of speech activity. When this purpose is achieved, a question, which sometimes seems far-fetched, often arises about mandatory or complementary nature of certain constituent components in a "typical course series" for teaching a foreign language due to the division of the latter into types of speech activity (listening, speaking, reading, writing) and aspects (phonetic, lexical and grammatical aspects of communication) for linguodidactic reasons. The above allows us to consider a foreign language "textbook" as a set of components that are equivalent for learning, each of which are called in our professional field separately a "learning aid", and for publishers - a "chrestomathy" and a "workbook" and otherwise in accordance with the Russian state standard (GOST 7.60-2003). An example of such a course series is "Simple Korean" course series (Voronina, 2018), and the modern publishing business is quite ready to release such a set consisting of the printed product on paper and applications on digital media. Until recently, publishers worked on creation of a paper version of the textbook (with the help of printing houses) supplementing it, if necessary, with its electronic (non-interactive) version or with an audio application (made in recording studios) and sometimes even with audiovisual application (made in video studios). But the real needs of today pose new challenges for the publishers. These needs require more integration of this course series with web applications (web apps) suggesting adjustments to the usual way of working for the publishers.

\section{Purpose and objectives of the study}

The purpose of the research is to create a shape of the XXI century textbook on a foreign language and to determine characteristics that distinguish an innovative textbook from its traditional model. The ultimate goal of the study is to list services that publishers should be ready to provide to teachers-developers of the 
technologies in teaching foreign languages in order to jointly create an innovative textbook of the XXI century that meets modern realities and trends in the development of society, and, in particular, in the teaching of foreign languages.

\section{Literature review}

The global COVID-19 pandemic has caused a massive transition including transition of the education systems to the online format, which requires a different approach to the organizing of education, in particular to the teaching of foreign languages. Due to the absence of strict limitations on the part of the authorities as to the choice of online tools (or web applications) when teaching, all kinds of means and digital technologies have come to the disposal of teachers, with the help of which everything that was only dreamed of a few years ago has become real. In this connection, it became relevant to operate with the concept of "electronic textbook" (e-textbook) (Sommers, Shin, Greenebaum, Merker \& Sanders, 2019; Leddo, J. et al, 2020). However, many scholars talked about a modern and actual e-textbook as "interactive textbook" (Van Horne, Russell \& Schun, 2016), "interactive digital textbook" (Bikowski, \& Casal, 2018) and "intelligent e-textbook" (Weber \& Brusilovsky, 2015; Boulanger \& Kumar, 2021) highlighting their various features in different ways.

As a part of our study, it was useful to track how the corresponding representations changed in a chronological order. So, M. I. Belyaev talked about: 1) detailed structuring of the course content as a whole including division of the course into small units; 2) interactivity; 3 ) presence of a variety of illustrative material; 4) presence of a glossary; 5) presence of controlling procedures and 6) presence of hyperlinks (Belyaev, 2012). E. V. Stolyarova and M. G. Fedotova talked about hypertextuality, a polycode nature of the text, interactivity, frame structure of the chapter, clear structuring of the material and special graphic design (Stolyarova \& Fedotova, 2016). N. I. Zamerchenko and A. V. Kuznetsov talked about: 1) integration with a dictionary and applications for working with vocabulary; 2) connection with authentic content in a foreign language; 3) complete automation of control; 4) automatic assessment of advance in learning; 5) ensuring personalization of the teaching process; 6) automated checking of the written works; 7) ensuring a constant collection of feedback (Zamerchenko \& Kuznetsov, 2018). E. V. Shirinkina already noted application of AR/VR/XR technologies, and, therefore, the main characteristics of the so-called textbook platforms are information content, ease of building an associative link, for example, when learning languages, development of long-term memory, as well as an increase in learners' motivation for the subject of learning (Shirinkina, 2020).

The analysis showed that the concept of a textbook at the beginning of the 21 st century and an electronic textbook, which is needed now, more than twenty years later, are two different concepts. The requirements for a textbook have been changing quite quickly, at least as rapidly as the corresponding technologies develop. For example, in today's option necessity to install (or download) the textbook on the learner's own electronic device after purchase is no longer considered mandatory, a link to the location of the textbook in the Internet is sufficient.

From the point of view of legal norms, the teacher-developer can publish an electronic textbook independently, but despite the positive experience of predecessors (Stolyarova \& Fedotova, 2016), to create a high-quality educational product in all respects it requires significant investments and solution of organizational issues related to taxes, interaction with artists, proofreaders, programmers, system 
administrators, advertisers, marketers, license administration, etc., which significantly distracts the teacher from the very essence of creating an educational product, and, thus, affects the final quality of the textbook not in the best way. That is why the teacher-developer still needs a publisher. Consequently, on the one hand, the publishers were faced with the question of changing organizational principles of their work by attracting specialists from the field of information and communication technologies (ICT), but, on the other, from a psychological point of view, most publishing houses cannot be restructured, as there is their mental lag behind technological progress. So, a help of teachers-developers is required with a clear formulation what attention exactly should be paid to by publishers, and it is necessary to help them understand what functionality of modern digital technologies should be used to create an educational product - a "new generation textbook".

\section{Methodology}

To formulate specific tasks for publishers, along with generalizing the previous experience of colleagues, we concluded to perform a comparative analysis of the concepts of "paper textbook" and "e-textbook". As a result of such analysis it became clear that the fundamental difference between an e-textbook and its paper counterpart (see Table 1) was interactivity, polymodality of the information it contains, and hypertext structure.

Table 1. Similarities and differences between traditional and electronic textbooks

\begin{tabular}{|c|c|c|c|}
\hline \multicolumn{2}{|r|}{ Parameters to compare } & $\begin{array}{c}\text { Traditional } \\
\text { textbook } \\
\text { (including "digital } \\
\text { representation of } \\
\text { the printed } \\
\text { edition") }\end{array}$ & E-textbook \\
\hline \multirow{4}{*}{$\begin{array}{l}\text { a nature of basic } \\
\text { information }\end{array}$} & $\begin{array}{l}\text { availability of } \\
\text { text information }\end{array}$ & $\sqrt{ }$ & $\begin{array}{c}\sqrt{ } \\
\text { availability of } \\
\text { hypertext }\end{array}$ \\
\hline & $\begin{array}{l}\text { availability of integral (graphic) images of } \\
\text { objects presented in a form that allows } \\
\text { viewing and printing, but does not allow } \\
\text { symbol-by-symbol processing }\end{array}$ & $\begin{array}{c}\sqrt{ } \\
\text { static }\end{array}$ & $\begin{array}{c}\sqrt{ } \\
\text { dynamic }\end{array}$ \\
\hline & availability of an audio track & $\begin{array}{l}\sqrt{ } \\
\text { as an additional } \\
\text { application only }\end{array}$ & $\sqrt{ }$ \\
\hline & $\begin{array}{l}\text { availability of multimedia (audiovisual) } \\
\text { track }\end{array}$ & $\begin{array}{l}\sqrt{ } \\
\text { as an additional } \\
\text { application only }\end{array}$ & $\sqrt{ }$ \\
\hline \multirow{2}{*}{$\begin{array}{c}\text { a way to } \\
\text { communicate with } \\
\text { a user }\end{array}$} & determined & $\sqrt{ }$ & $\sqrt{ }$ \\
\hline & interactive & & $\sqrt{ }$ \\
\hline \multirow[b]{2}{*}{ a way to install } & without installing on a PC hard drive & & $\sqrt{ }$ \\
\hline & with installing on a PC hard drive & $\begin{array}{l}\sqrt{ } \\
\text { as an additional } \\
\text { application }\end{array}$ & $\sqrt{ }$ \\
\hline
\end{tabular}


The term "interactivity" is interpreted differently in every science and in every area of human activities. In the proposed context, it is considered an ability of the information and communication system to actively and adequately respond to user actions (Sidorov, 2020). It should be noted here that feedback can be provided by both a programmed system and a person (teacher, assistant, instructor, laboratory assistant, student, etc.) on the other side of the screen of an electronic device. The advantage of a teaching tool with such a connection is great. With its help, a learner not only receives instant feedback and explanation from a remote teacher (i.e. interacts with the content), but also significantly saves time intended for mastering content in a foreign language within the designated topic. First of all, such interactivity opens up other opportunities for organizing the learner's independent work and its control. This means that outside the conditions of receiving direct feedback, learners receive it indirectly, through specially designed analytical web applications, which, as a rule, are embedded in learning platforms.

The teacher-developer develops a technology for teaching a specific foreign language, thinks over and puts a certain amount of linguistic content, speech and illustrative material (including comments to help a learner to overcome difficulties in the process of independent work) into the publishing software platform, tests the resulting educational product, and then offers it for use by learners. The process of use is visible to the teacher-developer (or to other inspector-assistant) through an interface inaccessible to learners in the form of analytical data, for example, about the time spent by learners to complete a particular task, the speed of its completion, etc. Moreover, this data can be visualized in a wide variety of forms, for example, as a graph, diagram, etc. The teacher (the trainer) can also manage the settings of analytical web applications: set the necessary time intervals, open or close access, for example, to comments, etc. The capabilities of automated analytics provide methodologists with invaluable material for conducting experimental researches in order to optimize and improve the learning process, in particular the process of learning foreign language, reducing the time and efforts of the teacher-developer, as well as improving quality of each component of the course series.

We can talk about interactivity of e-textbook with differentiation according to its conditional division into three levels: low, medium and high. An example of a low level of interactivity is the electronic textbook "In Korea they say that ..." (Voronina, 2019), where the learning process is implemented without illustrations and without illusion of immersion into a real communication situation - on the screen of an electronic device one can see only the text in Korean and tasks simulating conditional situational communication. In such cases, a publisher does not have to engage artists in the work. The concept of a low level of interactivity in an e-textbook is comparable to other linguodidactic concept of an "asynchronous communication" (Machado \& Fialho, 2020). Its peculiarity is that low requirements for data transmission channels, as well as low efficiency of communication, which makes working with an electronic textbook more convenient for both parties, is allowable with no simultaneous engagement required for the teaching process. However, it involves attraction of large material resources when creating an appropriate learning computer program. Interaction of joint learning participants can have various types of joint learning activities through the web applications created for this purpose. Moreover, it can be «Open Educational Resources (OER)» (Sepúlveda, A. et al., 2020), as well as «Massive Online Open Courses (MOOCs)» (MOOC.org, 2020). An e-textbook can claim to be exclusive. However, a learning computer program is created purposefully for a specific learning model, and such learning computer programs including combination with a different set of web applications can be of universal character for different groups of learners. 
From the examples above, we can see that interactivity also implies not only off-screen interaction of a learner (or learners) with a teacher, but also off-screen interaction of learners with each other. Moreover, their interaction can be carried out at the middle level of interactivity, when learning information is presented in the form of image. And a high level of interactivity is provided in the e-textbook by the presence of information presented in the form of multimedia with inclusion of animation, video, sound and "hypertext" (Rozina, 2016), as well as virtual reality, or 3D simulation of reality, which contributes to the polymodal perception of information, which in turn adds perceptions, thereby making learning more effective due to their more intense or spectacular presentation and synesthesia.

\section{Polymodality}

Thanks to the widespread use of electronic technical teaching aids (mainly due to teaching creativity and desire to conduct pedagogical experiments in the search for effective methodological solutions), it became possible to use "polycode text" (Semeniuk \& Gordienko, 2018) in a combination of "text-image-sound". It became possible for the teachers of foreign languages, who have been longing for the widespread use of hard-to-reach polycode texts in teaching, and, before the pandemic, managed to master numerous services for creation of such texts (Canva, inCollage, Super Screen Recorder, etc.), which were originally designed to optimize communication in social networks (Instagram, Facebook, etc.), to fully implement the principle of visibility that meets, among other things, aesthetic needs of modern young visuals (deNoyelles \& Raible, 2017).

At the same time, a huge stream of information from the screens of Internet-connected electronic devices literally overwhelms the involved recipients. The brain is satiated with its quantity and over-attracted by its quality, which causes not only selective perception among students, but also creation of new teaching ideas among teachers. So, for example, under the influence of a variety of information from all sides, the rethinking of ways to consider the concept "national-cultural component" in the process of teaching foreign languages took place. The national-cultural component has traditionally been perceived as a part of the semantics of the lexical unit, which constitutes the subject basis of communication with a foreign language. If, following R.K. Min'yar-Beloruchev, this part is considered as an "information reserve" (Min'yarBeloruchev, 1990) and its formation is organized during learning with activation of sensory channels, then the subject side, national-cultural side of intercultural communication supported by the relevant information will "shorten the distance" in establishing intercultural dialogue. This distance is determined by the information owned by the carriers of one culture and not owned by the carriers of other culture. In ethnopsycholinguistics, the absence of such information in comparison with other is called a "lacunae" (Anokhina, 2018). Replenishment of extralinguistic lacunae by means of polycode texts used as teaching aids occurs simultaneously with mastering of some form of linguistic unit. On the one hand, this greatly distinguishes the traditional paper textbook from its electronic counterpart with high level of interactivity, and on the other hand, it challenges the modern publishing business, which is also forced to follow the changes in society and adapt to the needs of contemporaries who want to teach and learn in a new way. In this case, a kind of the web constructor (web-designer application) is required to help perception and assimilation of "nationally colored" linguistic material. Information can inflow to a learner through all kinds of sensory channels with a dominant on its visual component due to the fact that this channel receives the maximum amount of information.

Thus, the publisher meets additional tasks to the task of creating a textbook of the future, i.e. search for the 
existing web-applications or organization of creation of new relevant web applications supported by necessary electronic devices. Work with different channels of perception is organized according to the principle of hypertext, which has been considered for quite a long time. And, as it was shown above, this is postulated as a mandatory requirement for an e-textbook today (Belyaev, 2012).

\section{Hypertext structure}

The predominant feature of the traditional textbook is an analytical presentation of the material with a linear-logical combination of vocabulary and grammar and with tasks for working with texts. In this connection with which the content components of the "learning aid" in the Russian linguodidactic tradition are: 1) theoretical material in the form of text or diagrams; 2) exercises (tasks and material to process) and 3) illustrations (black and white or color). Regarding the latter component, it should be noted that illustrations have become a stumbling block in contracts between authors, teachers-developers and publishers. The thing is that texts without illustrations are perceived as not entirely comfortable for today's readers, but, in an effort to ensure a low cost of publications, publishers prefer course series without illustrations at all or, in rare cases, with black and white images, in order to provide more guarantee as to the sale of the final product among consumers. The mass share of the Russian-speaking citizens who study foreign languages becomes more and more in comparison of the total number of all potential buyers every year, but it is still small. That is why the publishers are extremely reluctant to even insert black and white illustrations into the text of a textbook for teaching a foreign language, as this requires additional expenses for an artist. In addition, use of pictures instead of artistic images may raise a copyright issue, and although the Russian law is clearly on the side of those developers who can use other copyrighted resources without limitation exclusively for education, in some countries, for example, in the Republic of Korea, this is not the case at all. That's why the use of other people's copyrighted resources as illustrative material is not particularly welcome in order to avoid potential conflict situations. Text and only text - this is the desired content for today's publishers, who have mastered to work impeccably skillfully with it.

At the same time, the modern views of the teachers-developers on what exactly is necessary to make the course series (or with the help of what to teach), require, as indicated above, something completely different. Polymodal sources of information with a predominant visual component are necessary. In addition, the skill of distant communication with inclusion of visual elements of expressing one's own emotions, feelings, attitudes, moods, etc., becomes a sign of good form in communication. The analysis of trends in development of views on the concept of an e-textbook shows that considering all the other modalities close to real educational communication during its creation will also become a principle of its creation. So, for example, to fill extra-linguistic lacunae, it is necessary to use the information that must be associated by learners in the process of assimilating the lexical units of the target language, contributing to the accumulation of a system of meanings, which are common with the carriers of the target language. Such information, firstly, can come through different channels of perception, and, secondly, it can be organized in various forms, for example, an illustration, a 3D diagram, a (video)commentary, a comic strip, a poster, a meme, a video plot, a device for transmitting an odor, etc., the perception of which is organized through special linking windows that open the relevant information. Such organization of learning information is very convenient: you can either linger on it, or go further if the learners are already familiar with it. From an organizational point of view, hypertext contemplates hyperlinks not only to closed resources, but also to open ones. For example, in the course of the learning process, listening to the 
material of TV news in Korean, you should provide access to the relevant news site online to get acquainted with the actual news on the topic and to use this authentic material in learning "here and now". In this case, the hyperlink will link the publisher's electronic information base and the authentic information required for learning. Since the presence of the link "does not mean that the required information is provided to anybody who wants" (Belyaev, 2012), then the publisher will have to take care of its own "digital platform" (Asadullah, Faik \& Kankanhalli, 2018) to guarantee access to the necessary information material, which is linked by hyperlinks to the e-textbook. Therefore, for the publisher, there is an actual "technological problem of organizing access to Internet resources as well as the task of developing a unified technological learning platform that provides a formation of the network infrastructure for systematization of the distributed information" (Rozina, 2016).

\section{Results}

The obtained results of the research can be presented in the form of a final generalization of all things that that have been stated previously regarding innovations that modern publishers should consider closely when providing their services to universities and to teacher-developers of modern e-textbooks.

First, one should consider what kind of information and how structured information should be associated with lexical units that form the basis for the formation of the lexical side of communication in a foreign language, which inevitably leads to raising the question about necessity to change all the content components, especially the material for performing this or other task in exercises and illustrative material for them.

Secondly, a learning and methodical aid, which is a model of the learning process, becomes conceptually tied to a specific university and formed by its teachers and implemented under their control, becoming a kind of technological teaching platform-textbook, which turns into an integral part of the university. This raises the question of a kind of integration of publishing houses and universities, or the question of creating its own publishing house at the university, part of which is a team of specialized IT specialists. At the same time, strict observance of copyrights of the teacher-developer by the university ensures exclusion of opportunities for outside or temporarily invited teachers to take advantage of the fruits of other people's creations. In addition, it will prevent those, who do not wish to improve their methodological competence in any field of teaching foreign languages, from entering the education sector.

Thirdly, an electronic textbook (e-textbook, digital textbook) takes the form of a set, of a course series, constantly supplemented and updated and, thanks to its electronic form, with no republication, which are inevitable if a textbook exists exclusively in a paper form. The task of combining the editing program for printing with the one used by layout designers becomes relevant when excluding duplication of work operations.

Fourth, the publishers will have to develop or find and master such technological publishing platforms that correspond to the analyzed trends in the development of the concept of "textbook", reflecting the main directions of the development of education and the corresponding teaching aids of the XXI century.

\section{Discussions}

Today, among teachers of a foreign language there is no clear understanding of what a modern textbook should look like and what can be a shape of it. Some part of the teachers, in principle, are not inclined to 
delve into the essence of the methodological category called in Russian teaching tradition "teaching and methodological complex" (course series) because of low requirements to the methodological competence of the teacher at a specific workplace, while the other part does not make a difference between the printed (paper) edition, its PDF version and an interactive textbook. The rest of them already have experience not only of work, but also of independent creation and use of electronic publications in their professional teaching activities. Nevertheless, a progressive part of the colleagues is faced with insufficient technological readiness of publishers to make their products. In response, the publishers ask teachers of a foreign language to make a kind of the request for proposal, according to which a way to modernize editions of electronic educational literature could be outlined. In addition, the problems of copyright, marketing issues related to the distribution of an electronic textbook, and the technological part requiring engagement of professionally oriented IT specialists remain relevant. It seems promising for a university to choose one or other - teaching and, at the same time, publishing - technological platform and, subsequently, to enter together with a publishing house into a joint publishing project activities focused on the educational profile of the university, which would correspond to the modern trend towards changing the educational system in terms of creating original educational products including textbooks created for the tasks of each specific educational program, which every year will acquire the features of more and more exclusivity.

\section{Conclusion}

The XXI century foreign language textbook is represented as a kind of teaching computer program that has an interface and connects teachers-developers, students and publishers using web applications and as a kind of linguodidactics web constructor, which together represent a training course, or a technological platform, which enables collecting (correcting, updating, structuring) its content and form in accordance with actual tasks of teaching with methodically implemented feedback that permeates the entire process of teaching a foreign language.

\section{References}

Anokhina, T. (2018). The Linguistic Verification of Lacunae by the Modern Lacunology Studies. Research Trends in Modern Linguistics and Literature, 1, 4-16.

Asadullah, A., Faik, I. \& Kankanhalli, A. (2018, September). Digital Platforms: A Review and Future Directions. Pacis 2018 Proceedings (At Yokohama, Japan).

Azimov, E. G., \& Shchukin, A. N. (2019). Sovremennyi slovar' metodicheskikh terminov i ponyatii. Teoriya i praktika obucheniya yazykam [Modern dictionary of methodological terms and concepts. Theory and practice of language teaching]. Moscow, M.: Russkii yazyk. Kursy. 496 p.

Belyaev, M. I. (2012). Printsip realizatsii struktury giperteksta - odin iz osnovnykh printsipov sozdaniya elektronnykh uchebnikov [The principle of implementing the hypertext structure is one of the main principles of creating electronic textbooks]. Vestnik Rossiiskogo universiteta druzhby narodov. Seriya: Informatizatsiya obrazovaniya [Bulletin of the Peoples' Friendship University of Russia. Series: Informatization of education], 3, 71-82.

Bikowski, D. \& Casal, J. E. (2018, February). Interactive digital textbooks and engagement: A learning strategies framework. Language Learning \& Technology, 22(1), 119-136.

Bim, I. L., Afanas'eva, O. V. \& Radchenko, O. V. (1999). K probleme otsenivaniya sovremennogo uchebnika inostrannogo yazyka [On the problem of assessment of a modern foreign language textbook]. Inostrannye yazyki $v$ shkole [Foreign languages in schools], 6, 13-17.

Boulanger, D. \& Kumar, V. (2021, January). An Overview of Recent Developments in Intelligent eTextboos and Reading Analytics. 13 p. Retrieved from http://ceur-ws.org/Vol-2384/paper05.pdf 
deNoyelles, A., \& Raible, J. (2017). Exploring the Use of E-Textbooks in Higher Education: A Multiyear Study. Educause Review

GOST 7.60-2003 Izdaniya. Osnovnye vidy. Terminy i opredeleniya [Publications. The main types. Terms and definitions]. (2020, Desember, 20). Retrieved from http://docs.cntd.ru/document/1200034382

Leddo, J. et al. (2020). Artificial Intelligence and Voice-powered Electronic Textbooks and Electronic books. International Journal of Social Science and Economic Research, 5(1), 190-206.

Machado, A. de B., \& Fialho, F. (2020). Interaction and Interactivity Process: Communication in Digital Education. Journal of Information and Visualization, 67-73. https://doi.org/10.35877/454RI.jinav254

Manzoor, A. (2016). Dynamic Electronic Textbooks: A New Learning Experience. Applied Learning Theory and Design in Modern Education, 478-498.

Min'yar-Beloruchev, R. K. (1990). Metodika obucheniya frantsuzskomu yazyku [Methods of teaching the French language]. Moscow, M.: Prosveshchenie. 224 p.

MOOC.org (2020, Desember, 27). Retrieved from https://www.mooc.org/

Rozina, I. N. (2016). Printsipy uspeshnoi kommunikatsii na osnove giperteksta [The principles of successful communication based on the hypertext]. Vestnik Volgogradskogo gosudarstvennogo universiteta. Seriya 2: Yazykoznanie [Bulletin of the Volgograd State University. Series 2: Linguistics], 15(3), 37-46.

Semeniuk, T. \& Gordienko, Yu. (2018). From Text to Polycode Text: Semiotic Changes in Text Production. Research Trends in Modern Linguistics and Literature, 1, 122-134.

Sepúlveda, A. et al. (2020). The Digital Transformation of Education: Connecting Schools, Empowering Learners. Geneva: International Telecommunication Union (ITU); UNESCO; UNICEF.

Shirinkina, E. V. (2020). Platformy obucheniya v usloviyakh tsifrovoi transformatsii [Learning platforms in the context of digital transformation]. Nadezhnost' $i$ kachestvo slozhnykh system [Reliability and quality of complex systems], 1(29), 42-48.

Sidorov, S. V. Chto takoe interaktivnost' [What is interactivity]. (2020, Desember, 20). Sait pedagogaissledovatelya. Retrieved from si-sv.com/publ/1/chto_takoe_interaktivnost/14-1-0-523

Sommers, S. R., Shin, L. M., Greenebaum, S. L., Merker, J., \& Sanders, A. S. (2019). Quasi-experimental and experimental assessment of electronic textbook experiences: Student perceptions and test performance. Scholarship of Teaching and Learning in Psychology, 5(1), 1122. https://doi.org/10.1037/st10000129

Stolyarova, E. V., \& Fedotova, M. G. (2016). Teoreticheskie i prakticheskie voprosy sozdaniya elektronnogo uchebnika kak modeli obucheniya inostrannomu yazyku [Theoretical and practical issues of creating an electronic textbook as a model of the foreign language teaching]. Kontsept [Concept], 2 (fevral'). Retrieved from http://e-kon-cept.ru/2016/16036.htm.

Van Horne, S., Russell, J., \& Schun, K. L. (2016). The adoption of mark-up tools in an interactive etextbook reader. Educ. Technol. Res. Dev. 64, 407-433. https://doi.org/ 10.1007/s11423-016-9425-x

Voronina, L. A. (2018). Lingvodidakticheskaya kontseptsiya uchebno-metodicheskogo komplekta «Prostoi koreiskii» [Linguodidactic concept of the learning and methodical course series "Simple Korean"]. Gertsenovskie chteniya. Inostrannye yazyki. [Herzen readings. Foreign languages.], 284-286.

Voronina, L. A. (2019) V Koree govoryat, chto ... [In Korea they say that ...]. Moscow, M.: KDU.

Weber, G. \& Brusilovsky, P. (2015). ELM - An Interactive and Intelligent Web-Based Electronic Textbook. International Journal of Artificial Intelligence in Education, 26(1). https://doi.org/10.1007/s40593-015-0066-8

Zamerchenko, N. I., \& Kuznetsov, A. V. (2018). Model' elektronnogo uchebnika po inostrannomu yazyku novogo pokoleniya $\mathrm{v}$ usloviyakh vvedeniya FGOS i professional'nogo standarta pedagoga [Model of the foreign language electronic textbook of a new generation in the context of introduction of the Federal State Educational Standard and the professional standard of a teacher]. Filologicheskie nauki. Voprosy teorii i praktiki [Philological sciences. Questions of theory and practice], 1(79), 417-419. https://doi.org/10.30853/filnauki.2018-1-2.52 